\title{
High rate algal pond treatment for water reuse in a marine fish recirculation system: Water purification and fish health
}

\author{
E. Metaxa ${ }^{a}$, G. Deviller ${ }^{b}$, P. Pagand ${ }^{c}$, C. Alliaume ${ }^{d}$, C. Casellas $^{b}$ and J.P. Blancheton ${ }^{a,{ }^{*}}$ \\ alFREMER, Station de Palavas, Chemin de Maguelone, 34250 Palavas Les Flots, France \\ bDépartement Sciences de l'environnement et Santé Publique, Université de Montpellier 1, UMR \\ 5556, Faculté de pharmacie, 15 avenue Charles Flahaut, 34060 Montpellier, France \\ cUniversité de Nouvelle Calédonie, LERVEM, BP 4477, 98847 Nouméa, Nouvelle Calédonie, France \\ dUMR CNRS-UMII 5119, Ecosystèmes Lagunaires. Université Montpellier II, cc 093, Place E. \\ Bataillon, 34095 Montpellier Cedex 5, France \\ *: Corresponding author : Jean.Paul.Blancheton@ifremer.fr
}

\begin{abstract}
:
Regardless of the degree of closure of a recirculation system, effluents are produced and replacement water is needed, which limits the possibility of locating a seawater production system away from the shoreline. At the Palavas Ifremer station, in the south of France, a High Rate Algal Pond (HRAP) was operated during several years to treat the effluent from a recirculating aquaculture system before reusing it. The effect of the HRAP-treated water on the recirculation system and on the fish was investigated and the optimal algae growing conditions were defined. The experiments were carried out in three rearing systems: one flow through, one recirculating and one recirculating with a HRAP. The water flow rate, temperature, $\mathrm{pH}$ and salinity conditions were similar in all systems.

The effect of reusing the HRAP-treated water is very limited (1) on the functioning of the recirculation system and (2) on fish performance, but it allows a significant reduction of the dissolved inorganic nitrogen and phosphorus concentration in the rearing water. HRAP treatment reduced metal accumulation in muscle and liver of RAS fish, except for chromium and arsenic. All biomarkers presented no significant difference between systems, except for Superoxide Dismutase (SOD) and EROD, which showed a higher concentration in RAS and in both recirculating system respectively. (c) 2005 Elsevier B.V. All rights reserved.
\end{abstract}

Keywords: Recirculation aquaculture systems; Aquaculture effluent; Macroalgae; High rate algal pond; Fish health 


\section{Introduction}

Environmental concerns and limitation in water availability are some of the factors that make recirculation systems an important option for the aquaculture industry. However, water reuse is limited by the accumulation of waste products excreted by fish, such as carbon dioxide, ammonia-nitrogen, and particulate and dissolved faecal solids (Lemarié and Toften, 2003). In addition, nitrate and phosphate levels accumulate in the water of recirculation systems as a result of biofiltration at a rate dependent on fish density and water replacement flow rate (Pagand et al., 2000a, Leonard et al., 2002).

A method of improving effluent marine water quality characterised by high nutrient concentrations, especially nitrate, is to use high rate algal pond (Pagand et al., 2000a; Deviller et al., 2004). An advantage of a high rate algal pond containing mainly macroalgae is that algal material can be harvested relatively easily. Macroalgae can absorb significant quantities of dissolved inorganic and organic nutrients, usually with a preference for $\mathrm{NH}_{4}{ }^{+}$(D'Elia \& DeBoer, 1978; Haines \& Wheeler, 1978; Hanisak \& Harlin, 1978; Harlin, 1978; A.Jones, 1999). The ability of macroalgae to rapidly take up nutrients for growth, and store luxury reserves in the form of amino acids and pigments makes them ideal for stripping nutrients from aquaculture effluent (Haines, 1975; A.Jones, 1999).

Research on the use of macroalgae for the treatment of marine aquaculture wastes began 10 years ago at a research institute based in the south of France (IFREMER, Palavas), as part of a pilot experiment for high fish density (around $100 \mathrm{~kg} / \mathrm{m}^{3}$ ) farming of Dicentrarchus labrax L. The incorporation of a high rate algal pond (HRAP) as a separate water treatment loop in a recirculation system yielded high nutrient reclamation and clean effluents (Pagand et al., 2000b). The macroalgae that developed spontaneously in the HRAP were species such as Ulva, Enteromorpha and Cladophora. The input water to the HRAP contained an average of $1.3 \mathrm{mg} . \mathrm{L}^{-1}$ reactive phosphorus and $10.2 \mathrm{mg} . \mathrm{L}^{-1}$ dissolved inorganic nitrogen, of which more than $80 \%$ was in the form of nitrate. The algal pond removed $59 \%$ of the dissolved nitrogen and $56 \%$ of the phosphorus input, which were converted into $3.3 \mathrm{~kg}$ dry weight of algae per $\mathrm{m}^{2}$ (of which $5 \%$ was phytoplankton). During the optimal climatic conditions, only $150 \mathrm{~m}^{2}$ of treatment ponds would be necessary to remove the nutrients produced by 1 ton of fish. Treated water was characterised by a high $\mathrm{pH}$, elevated levels of dissolved oxygen (midday value) and low concentrations of nutrients and suspended solids. The absence of toxic phytoplankton meant that the water could be recycled through the fish tanks (Pagand et al., 2000b).

Seaweed biofiltration of fish farm effluents rose an increased interest in Portugal, where Falkenbergia rufolanosa proved to be an excellent alternative to the most frequently used macroalga in polyculture, Ulva spp, as it showed both higher nitrogen uptake rate, biomass yield and a higher commercial value (Mata et al., 2004, Schuenhoff et al., 2004).

Research on the long-term effect of the reuse of HRAP-treated water on fish performance and health was carried out at the IFREMER Palavas station (Deviller et al., 2005). European sea bass were reared for one year in three different systems: one flow through (FTS), one recirculating (RAS) and one recirculating with a high rate algal pond treatment (RAS+HRAP).

Over the past decade, the biomarkers have attracted a great deal of interest, molecular and cellular biomarkers have been extensively used in pollution monitoring in aquatic environments (McCharty and Shuggart, 1990, Hugget et al., 1992, Ph. Garrigues et al., 2001). Biomarkers can serve as quantitative measures of aquatic environment exposure as well as early warning signals of biologic effect. Few biomarkers were used for comparing the three types of aquaculture systems (FTS, RAS, RAS+HRAP) but the most relevant were Ethoxyresorufin-O-Deethylase (EROD), Superoxide dismutase (SOD) and liver protein (LP). EROD activity, a catalytic measurement of cytochrome P4501A induction, is an extremely sensitive indicator of environmental alterations and is usually one of the first detectable, quantifiable responses to exposure (Stegeman, 1992, Christopher J. Schmitt and Gail Dethloff, 2000). SOD are metalloenzymes that play major roles in protection of cells against 
oxidative damage. Because the metabolism is generally highest in hepatic tissue, the assay was conducted in liver tissue.

This study examines the research findings on the impact of HRAP wastewater treatment on the biological responses and performance of fish to identify further topics for research and developments in this area.

\section{Material and methods}

\subsection{Rearing system facilities}

The experiment was conducted over one year in three different rearing systems (FTS, RAS and RAS+HRAP) at the IFREMER Palavas facility in south of France. Each system consisted of two $2 \mathrm{~m}^{3}$ self cleaning fish rearing tanks. A general diagram of the systems is presented in Figure 1, and the main operational features of the components of the system are described in Table 1.

In FTS ( $5 \mathrm{~m}^{3}$ total volume), considered as a control, filtered seawater $\left(6 \mathrm{~m}^{3} \mathrm{~h}^{-1}\right)$ passed through a UV lamp, a heat exchanger, a degassing column and an oxygenation device before flowing into the fish tanks.

The RAS $\left(6 \mathrm{~m}^{3}\right)$, described by Blancheton (2000), was composed of the rearing tanks connected to a recycling loop through which the water circulated. In the recirculating loop, the largest particles were allowed to sediment in a particle separator, and the finer particles were retained on a mechanical filter (30 $\mathrm{mm}$ mesh). Carbon dioxide produced by the fish was partly removed in a counter current degassing column before the water entered the pumping tank, where sodium hydroxide (to avoid a drop in $\mathrm{pH}$ and an excess of dissolved carbon dioxide) and oxygen were added. The filtered and aerated mixture water was pumped into a UV disinfection unit to prevent bacterial development, and then through a nitrifying biofilter.

The RAS+HRAP $\left(18 \mathrm{~m}^{3}\right.$ total volume) was similar to the RAS but a part of the effluent $\left(0.7 \div 1 \mathrm{~m}^{3} \mathrm{~h}^{-1}\right)$ was treated in two separate outdoor HRAP functioning in parallel, before passing through the biological filter, as described by Pagand et al. (2000b). Each of the ponds had a surface area of 11.8 $\mathrm{m}^{2}$, a depth of $0.5 \mathrm{~m}$ and a volume of $5.9 \mathrm{~m}^{3}$. They were in operation 4 months before the experiment was started, using effluent from another seabass rearing tank and the algal biomass was managed according to Deviller et al. 2004.

\subsection{Experimental conditions}

Rearing tanks were stocked at a fish density of $10 \pm 2 \mathrm{~kg} / \mathrm{m}^{3}$ (mean \pm standard deviation (SD) with 9 months old sea bass (Dicentrarchus labrax) from a nearby farm, with a starting weight of $35 \pm 11 \mathrm{~g}$ (mean \pm SD). Self-feeders fitted with a tactile trigger, as described by Coves et al. (1998), were supplied with a commercial diet (Neostart $3 \AA$, Bar D Extra Natura $4 \AA$, Bar D Extra Natura $5 \AA$ ) containing 44 to $52 \%$ protein, $1.5 \%$ phosphorus, $22 \%$ fat, $2 \%$ crude fibre and $10 \%$ ash. The total quantity of feed consumed by the fish between two biomass sampling periods was measured by weighing the daily feed which was left in the self-feeder, by a HUSKY computer connected to the trigger.

In both recirculating systems, the replacement water flow rate was adjusted twice a week, maintaining a constant water use relative to feed of $\mathrm{R}=1$ to $3 \mathrm{~m}^{3} . \mathrm{kg}^{-1}$. In the FTS, the replacement water flow rate was constant, resulting in $\mathrm{R}=41$ to $79 \mathrm{~m}^{3} \cdot \mathrm{kg}^{-1}$ throughout the experiment. Water flow rate to each of the tanks was maintained at $3 \mathrm{~m}^{3} / \mathrm{h}$ for all the systems.

Water quality parameters within the three rearing systems (FTS, RAS, RAS+HRAP) were monitored daily using hand held devices and were adjusted as following: temperature $\left(22 \pm 2^{\circ} \mathrm{C} ; 23 \pm 2^{\circ} \mathrm{C}\right.$; $\left.23 \pm 2^{\circ} \mathrm{C}\right)$, salinity $\left(38 \pm 3\right.$ g..$^{-1} ; 32 \pm 3$ g..$^{-1} ; 31 \pm 6$ g. $\left.l^{-1}\right), \mathrm{pH}(7.8 \pm 0.2 ; 7.0 \pm 0.3 ; 7.1 \pm 0.3)$ and oxygen concentration (7.7 \pm 1.7 mg..$^{-1} ; 7.3 \pm 1.2$ mg..$^{-1} ; 7.8 \pm 1.4$ mg..$\left.^{-1}\right)$. Values represent mean \pm SD. 


\subsection{Fish sampling}

Forty randomly chosen fish were sampled monthly, during one year, and weighed in anaesthesia. At the end of the experiment, all the fish were counted, and thirty fish per rearing system were sacrificed by a blow to the head. The liver and muscle samples were collected for enzymatic and metal assessment.

\subsection{Fish biometrics}

The fish density $\left(D_{\mathrm{f}}\right.$ expressed as $\mathrm{kg} / \mathrm{m}^{3}$ and the specific growth rate (SGR) expressed in $\%$ day $^{-1}$ were calculated using the following formulae:

$\mathrm{D}_{\mathrm{f}}=\mathrm{m} \times \mathrm{N} /\left(1000 * \mathrm{~V}_{\mathrm{t}}\right)$

where $\mathrm{m}=$ average mass of the fish $(\mathrm{g}) ; \mathrm{V}_{\mathrm{t}}=$ volume of the rearing tanks $\left(\mathrm{m}^{3}\right) ; \mathrm{N}=$ number of fish in the tanks.

$\mathrm{SGR}=\left[\ln \left(\mathrm{m}_{\mathrm{f}}\right)-\ln \left(\mathrm{m}_{\mathrm{i}}\right)\right] \times 100 / \mathrm{t}$

where $\mathrm{m}_{\mathrm{i}}=$ initial average mass $(\mathrm{g}) ; \mathrm{m}_{\mathrm{f}}=$ final average mass $(\mathrm{g}) ; \mathrm{t}=$ time (day).

Daily ingested food (DIF) was assumed to be equal to the feed applied to the tanks and was expressed as g/fish per day. The DIF and feed conversion ratio (FCR) were calculated from the daily data recorded by using the following formulae:

$\mathrm{DIF}=(\mathrm{DF}-\mathrm{NIF}) /\left[\mathrm{t} \times\left(\mathrm{N}_{\mathrm{i}}+\mathrm{N}_{\mathrm{f}}\right) / 2\right]$

where DF = distributed food, or feed added to the feeders (g); NIF = non ingested food, or feed remaining in the feeders $(\mathrm{g}) ; \mathrm{N}_{\mathrm{i}} \& \mathrm{~N}_{\mathrm{f}}=$ initial \& final number of fish in the tanks; $\mathrm{t}=$ time (day).

$\mathrm{FCR}=(\mathrm{DF}-\mathrm{NIF}) /\left[\left(\mathrm{m}_{\mathrm{f}} \times \mathrm{N}_{\mathrm{f}}\right)-\left(\mathrm{m}_{\mathrm{i}} \times \mathrm{N}_{\mathrm{i}}\right)\right]$

The condition factor (CF) was calculated according to Bagnenal and Tesch (1978):

$\mathrm{CF}=\left(\mathrm{m} /\left(\mathrm{L}_{\mathrm{fish}} / 10\right)^{3}\right) * 100$ where $\mathrm{L}_{\text {fish }}=$ average length of the fish $(\mathrm{mm})$

The liver somatic index (LSI) was calculated according to Slooff et al. (1983):

$\mathrm{LSI}=\left(\mathrm{m}_{\text {liver }} / \mathrm{m}\right) * 100$

where $\mathrm{m}_{\text {liver }}=$ mass of the liver $(\mathrm{g})$

\subsection{Water sampling and analysis}

The water temperature and incident light on the HRAP were recorded automatically every five minutes for estimating their influents on the HRAP nutrient removal rates. Water samples were collected three times per week during four periods of two months corresponding to the seasons, at 9 o'clock from the FTS outlet, and the inlets to the biological filters in the RAS and RAS+HRAP. Samples were filtered on rinsed GF/C Wathman ${ }^{\circledR}$ filters and analysed with Technicon ${ }^{\circledR}$ Autoanalyzer II (Treguer \& Le Corre (1974) as follows: the total ammonia nitrogen (TAN) concentration was measured using the method described by Solorzano (1969); nitrite nitrogen $\left(\mathrm{NO}_{2}-\mathrm{N}\right)$ was measured by molecular absorption method described by Bendschneider and Robinson (1952); nitrate nitrogen $\left(\mathrm{NO}_{3}-\mathrm{N}\right)$ was measured using the same technique as nitrite after a primary reduction to nitrite on a cadmium-copper column (Wood et al., 1967); and phosphate phosphorus $\left(\mathrm{PO}_{4}-\mathrm{P}\right)$ was measured using the spectrophotometric method (AFNOR NF T 90-023) described by Murphy and Riley (1962). The sum of TAN, nitrite and nitrate is equal to dissolved inorganic nitrogen (DIN). The concentration of unionised ammonia (UIA) was calculated using the equation of Johansson and Wedborg (1980).

HRAP removals ( $\mathrm{R}_{\text {HRAP }}$ g. $\mathrm{m}^{-2}$ day $^{-1}$ ) (means \pm standard deviation) of two-month values were calculated for each season by comparison of the nutrient levels in the two recirculating systems. Removal rates were expressed according to the total HRAP surface $\left(24 \mathrm{~m}^{2}\right)$ :

$\mathrm{R}_{\text {HRAP }}=\left[\left(\mathrm{RW}_{\mathrm{r}} \times\right.\right.$ nut $\left._{\mathrm{r}}\right)-\left(\mathrm{RW}_{\mathrm{rHRAP}} \times\right.$ nut $\left.\left._{\mathrm{rHRAP}}\right)\right] /\left(\mathrm{S}_{\text {HRAP }} \times 1000\right)$

where $\mathrm{RW}_{\mathrm{r}}=$ replacement water in RAS (liter day ${ }^{-1}$ ); $\mathrm{RW}_{\mathrm{rHRAP}}=$ replacement water in RAS+HRAP (liter day $^{-1}$ ); nut $\mathrm{r}_{\mathrm{r}}=$ nutrient concentration in RAS $\left(\mathrm{mg} . \mathrm{l}^{-1}\right)$; nut $_{\text {rHRAP }}=$ nutrient concentration in RAS + HRAP $\left(m g . l^{-1}\right) ; S_{\text {HRAP }}=$ surface of the $\operatorname{HRAP}\left(\mathrm{m}^{2}\right)$. 


\subsection{Biomarker and trace metals analysis}

Levels of three enzyme biomarkers: liver protein (LP), ethoxiresorufin-0-deethylase (EROD), and superoxide dismutase (SOD), were measured in the fish of the three rearing systems to assess the impact of the rearing environment on fish health. The LP was assessed with the method of Bradford (1976), the EROD activity was measured according to the method of Flammarion et al. (1998) and the SOD enzymatic activity was assessed using the method of Paoletti et al. (1986). Selected heavy metals (Cr, Mn, Co, Ni, Cu, Zn, As, Ag, Cd, Sn, Tl, Pb) were measured in the liver and muscle. Liver and muscle samples were analysed using the techniques described by Deviller, 2005.

\subsection{Statistic analysis}

The data on nutrient concentrations were assessed using one-way analyse of variance (ANOVA) with the rearing system (FTS, RAS, RAS+HRAP) as the factor. The two-way ANOVA was used for the data on fish weight with the two rearing tanks and the different rearing systems as factors. One-way ANOVAs were used for comparison of body weight, length, LSI, CF, liver biomarkers, and muscle and liver metals of fish from the three rearing systems.

As variances were not homogenous, a natural logarithm transformation of data was performed prior to carrying out the statistical analysis. If the variances were still not homogeneous, then more statistical analysis were performed such the Tuckey test, the non-parametric test of Kruskal-Wallis, the Newman-Keuls test and the Spearman correlation analyse.

\section{Results and discussions}

\subsection{Quality of rearing water}

Figure 2 shows the temperature, oxygen concentrations, salinity and $\mathrm{pH}$ recorded within the rearing systems. It was difficult to maintain constant water parameters throughout the entire experiment. The water salinity fluctuated due partly to the fresh water used to clean the mechanical filters of the recirculation systems, and partly to changes in the local seawater. Summer heat caused increased indoor air temperatures and a maximum of $29^{\circ} \mathrm{C}$ was reached in the RAS. The pH adjustments (at $\mathrm{pH}=6.5)$ were made with sodium hydroxide $(\mathrm{NaOH})$, of which more was added to the RAS comparing to the RAS+HRAP. It was difficult to maintain an optimal oxygen level at the end of the experiment when fish density reached $70 \mathrm{~kg} / \mathrm{m}^{3}$ and the oxygen demand increased.

The concentrations of TAN, $\mathrm{NO}_{2}-\mathrm{N}, \mathrm{NO}_{3}-\mathrm{N}$ and $\mathrm{PO}_{4}-\mathrm{P}$ in the rearing water are shown in Table 2. The nutrients concentrations in FTS were low because of their continuous removal by water exchange. The annual DIN and $\mathrm{PO}_{4}-\mathrm{P}$ concentrations were significantly lower in the RAS+HRAP relative to the RAS $(\mathrm{p}<0.01)$. The concentration of DIN remained lower in the RAS+HRAP relative to the RAS due to absorption of nitrate by macroalgae, (NK test, $\mathrm{p}<0.05$ ).

There were not statistically significant differences in TAN concentrations between the two recirculating systems. Phosphate concentrations were statistically lower in the RAS+HRAP compared with the RAS during winter (KW test, $\mathrm{p}<0.001$ ) and summer (NK test, $\mathrm{p}<0.05$ ) but similar during spring (ANOVA, $\mathrm{p}=0.09$ ) and higher in autumn (NK test, $\mathrm{p}<0.05$ ).

\subsection{Nutrient removal rates}

The nitrogen removals were strongly influenced by climatic conditions with the highest nitrogen removal occurring during the summer. The nitrogen removals were not statistically different during spring and autumn. The highest phosphate removal occurred during summer and was 10 times larger than during winter. There was a net increase (negative removal) of phosphate during spring and autumn. Table 3 presents the seasonal and annual removal rates of dissolved nutrients by the two HRAP estimated by comparing nutrient concentrations in the RAS and in the RAS+HRAP. 
The nitrogen and phosphate removals were strongly influenced by season and were highest during summer. On yearly average, the RAS+HRAP relative to the RAS showed 25\% removal of DIN, while only $9 \%$ of the $\mathrm{PO}_{4}-\mathrm{P}$ was removed. In a previous study, Pagand et al., (2000b) obtained three and five times higher maximal DIN and $\mathrm{PO}_{4}-\mathrm{P}$ removal rates, respectively, which could be explained by differences in the methods that he used: (1) the time of water sampling (14:00) that corresponded to the time of maximal photosynthetic rate; (2) the high hydraulic residence time in the HRAP (4 d) which results in a high $\mathrm{pH}$ and precipitation of $\mathrm{PO}_{4}-\mathrm{P}$ and (3) a more precise calculation of HRAP removal capacities by comparison of nutrient concentrations at the entrance and the exit of the pond. In addition, a shorter hydraulic residence time in the HRAP should partly make up for inorganic carbon depletion in high nitrate and phosphate effluents (Deviller et al., 2004). Future work should include twice per day sampling at the entrance and exit of the pond to determine the dynamics and mass balances of nutrients.

\subsection{Fish performances}

There was not difference in weight gain among the fish in the two replicate tanks for each rearing system and the data were pooled. Mean fish weight increased more in the flow through rearing systems and mean specific growth rates (SGR) were 0.66(RAS+HRAP) and 0.70(FTS). The fish in all the rearing systems exhibited similar growth during the first 126 days of the experiment. However, the mean growth was 15\% higher in FTS than in both RAS after this period (fig 3).

Slower overall growth rates in both RAS may be caused by the possible accumulation of chemical compounds produced by the fish or in the biofilter. The concentrations of TAN and UIA were far from $6.6 \mathrm{mg} \mathrm{l}^{-1}$ and $0.26 \mathrm{mg} \mathrm{l}^{-1}$, respectively, which are the chronic sub-toxic concentrations for sea bass (Lemarié et al., 2004). In a recent study (Lemarié and Toften, 2003), it was reported that accumulation of carbon dioxide at a water flow rate below $20 \mathrm{l} \mathrm{h}^{-1} \mathrm{~kg}^{-1}$ (of fish) in a flow through system, led to lower feed intake and sea bass growth.

After the month of maximum photosynthetic activity, the seabass reared in RAS+HRAP system showed a significantly higher mean weight than fish reared in FTS and RAS. These results suggest the beneficial effect of reusing HRAP treated water when climatic conditions are optimum for algae photosynthesis.

Feed conversion ratios were ranging from 1.53 (FTS) to 1.69 (RAS). Mortalities over the experimental period were less than $10 \%$ per year for all rearing systems (fig. 4), being lower in the RAS+HRAP. Not significant differences were found among rearing systems for CF and LSI.

The fish appeared to be safe from pathogens throughout the experiment and no histopathologies were evident in liver and muscle samples taken from fish. No chemical treatment was used.

\subsection{Biomarker analysis}

The results for LP, EROD, and SOD are given in Table 4. The results of one way ANOVA did not indicate any statistically significant differences among the three kinds of rearing systems with respect to LP. Seabass was shown to be a very sensitive species concerning liver biotransformation responses (Gravato and Santos, 2002).

However, the results of ANOVA showed that the SOD activity and EROD concentrations increased in the RAS relative to the FTS. The increase may be caused by pollutant exposure (Deviller et al. 2005). Another hypothesis is that EROD activity of FTS fish was inhibited by long exposition to low levels of pollutants in replacement water. The data for the three biomarkers in question have been difficult to interpret and this suggests that more calibration studies are necessary to determine what induces the SOD and EROD activity differences among rearing systems. 


\subsection{Metals analysis}

Table 5 lists the length and weight ranges of sampled fish for metal assessment in each rearing system and the mean metal concentrations ( $\mathrm{Cr}, \mathrm{Mn}, \mathrm{Co}, \mathrm{Ni}, \mathrm{Cu}, \mathrm{Zn}, \mathrm{As}, \mathrm{Ag}, \mathrm{Cd}, \mathrm{Sn}, \mathrm{Tl}, \mathrm{Pb}$ ) in the muscle and liver of fish.

The weight and length averages did not differ significantly in the three systems. There was not found significant correlation $(\mathrm{p}<0.05)$ in metal concentrations (muscle or liver) and fish size (length or weight).

Two of the twelve metals measured in muscle, as zinc and arsenic, indicated the assumption of normality. Concentrations of chromium, manganese, cobalt, nickel, copper, arsenic and thallium were significantly higher in the muscle of fish from the RAS compared to the FTS. In the RAS+HRAP, only chromium and arsenic showed significantly increased concentrations in fish muscle compared to the FTS.

The mean metal concentrations in muscle and liver tissues showed large variations for the same rearing system. These variations were higher in muscle than in liver where metal concentrations are more homogeneous. Concentrations of chromium, cobalt, cadmium and lead were significantly higher in livers of fish from the RAS compared to the FTS. The livers of the fish from RAS+HRAP had significantly increased chromium and reduced tin compared to the FTS. Compared to muscle, the liver had a tendency to accumulate more manganese, cobalt, copper, zinc, silver, cadmium, tin and thallium, while arsenic was significantly lower in liver than in muscle. However, the level of metals in fish muscle and liver was less than the maximum limits demonstrated by literature.

Further analyses of the relationship between heavy metal concentration in fish organs, in rearing water, and in commercial food are necessary to confirm these results and to explore factors which govern metal accumulation of fish reared in the recirculating aquaculture systems. It is suggested that metal concentrations in fish be explored in future research over more fish samples to determine the levels more precisely.

\section{Conclusions and prospects}

Although some advances have been made in aquaculture recirculation systems, there is limited information on the long-term effect of RAS water on fish health and performance. In our experiments, the use of macroalgae was shown to improve water quality in the system over a period of one year and the HRAP-treated water did not induce fish mortality, biological filter disturbance or delays in fish growth. The mortality rate of the fish reared in RAS+HRAP was half of those in the other two rearing systems. The accumulation of metals in fish was lower in the RAS+HRAP than in the RAS system, except for chromium and arsenic. The incorporation of a HRAP as a second loop in a high-density RAS has beneficial implications in effluents treatment where metabolic waste products are the main concern.

Aquaculture effluent treatment techniques usually involve additional costs. However, if the treatment itself produces income and reduces water requirements and environmental impact of RAS effluents, it can improve the economic sustainability of an aquaculture system. Recent research on species diversification and improvement of aquatic production in seaweeds purifying effluents from integrated fish farm activity revealed the use of new seaweed species as biofilters for mariculture. The red seaweed, Falkenbergia rufolanosa, was found as an excellent biofilter for temperate latitudes and colder water as well easily tank-cultivated and fast growing (A. Schuenhoff et al., 2003). These results should be used to improve RAS wastewater treatments, while the algal biomass is valorised.

A model of wastewater purification has to be designed as algae growth prediction based on effluents parameters such nitrogen, phosphorus, dissolved oxygen, temperature and light, having into consideration the changing seasonal pattern of these variables.

A well designed recirculating aquaculture system in a completely enclosed environment should be the aim of further research as the environmental impact of effluent discharge from aquaculture facilities is a growing concern for policy makers. In addition, flexibility in site selection and limitations in water 
availability are important reasons for considering RAS as a commercially viable option to provide a reliable supply high-quality fish.

\section{Acknowledgements}

The authors greatly acknowledge Prof. Dr. Raul H. Piedrahita and Dr. Arnaud Muller Feuga for their helpful suggestions and comments to improve the manuscript. Also, the authors would like to thank the all anonymous reviewers for their insightful comments and suggestions.

\section{References}

Bagenal, T.B., Tesch, F.W., 1978. Methods for assessment of fish production in fresh waters. In: Bagenal, T.B. (Ed), Age and growth. Blackwell Scientific Publications. Oxford, pp. 101-136.

Benschneider, K., Robinson, R.J., 1952. A new spectrophotometric determination of nitrite in seawater. J. Mar. Res. 11, 87-96.

Blancheton, J.P., 2000. Developments in recirculation systems for Mediterranean fish species. Aquacult. Eng. 22, 17-31.

Bradford, M.M., 1976. A rapid sensitive method for the quantification of microgram quantities of protein utilizing the principle of protein-dye binding. Analytical Biochemistry 72, 248-254.

Coves, D., Gasset, E., Lemarié, G., Dutto G., 1998. A simple way of avoiding feed wastage in European seabass, Dicentrarchus labrax, under self-feeding conditions. Aquat. Living Resour. 11, 395-401.

Deviller, G., Aliaume, C., Franco Nava, M.A., Casellas, C., Blancheton, J.P., 2004. High rate algal pond treatment for water reuse in an integrated marine fish recirculating system: effect on water quality and seabass growth, Aquacult. 235, 331-344.

Deviller,G., Palluel, O., Aliaume, C., Asanthi, H., Sanchez, W., Franco Nava, M.A., Blancheton, J.P., Casellas, C., 2005. Impact assessment of various rearing systems on fish health using multibiomarker response and metal accumulation. Ecotoxicology and Environmental Safety, In Press.

D’Elia, C.F., DeBoer J.A., 1978. Nutritional studies of two red algae. II. Kinetics of ammonium and nitrate uptake. J. Phycol. 14, 105-113.

Flammarion, P., Migeon, B., Urios, S., Morfin, P., Garric, J., 1998. Effect of methidathion on the cytochrome P-450 1A in the cyprinid fish gudgeon (Gobio gobio). Aquat. Toxicol. 42(2), 93102.

Garrigues, Ph., Barth, H., Walker, C.H., Narbonne, J.F., 2001. Biomarkers in marine organisms : A practical approach. Elsevier Science, pp. 215 - 236.

Gravato, C., Santos, M.A., 2002. Juvenile Sea Bass Liver P450, EROD Induction, and Erythrocytic Genotoxic Responses to PAH and PAH-like Compounds. Ecotoxicology and Environmental Safety 51, 115-127.

Haines, K.C., Wheeler. P.A., 1978. Ammonium and nitrate uptake by the marine macrophytes Hypnea musciformis (Rhodophyta) an Macrocystis pyrifera (Phaephyta). J. Phycol. 14.

Harlin, M.M., Thorne-Miller, B., Thrusby, G.B., 1978. Ammonium uptake by Gracilaria sp. (Flordeophyceae) and Ulva lactuca (Chlorophyceae) in closed system fish culture. Proc. Int. Seaweed Symp. 10, 285-292.

Hugget, R.J., Unger, M.A., Seligman, P.F., Valkirs, A.O., 1992. The marine biocide tributyltin: Assessing and managing the environmental risks. Environ. Sci. Technol. 26, 2, 232-237.

Jones, A., 1999, Thesis "Environmental Management of Aquaculture Effluent: Development of Biological Indicators and Biological Filters", 1999, http://www.cms.uq.edu.au/marbot/publications

Johansson, O., Wedborg, W., 1980. The ammonia-ammonium equilibrium in sea water at temprature between 5 and $25^{\circ} \mathrm{C}$. Journal of Solution Chemistry 91, 37-44. 
Lemarié, G., Dosdat, A.; Coves, D.; Dutto, G.; Gasset, E.; Person-Le Ruyet, J., 2004. Effect of chronic ammonia exposure on growth of European seabass (Dicentrarchus labrax) juveniles. Aquaculture 229, 479-491.

Léonard, N., Guiraud, J.P., Gasset, E., Cailleres, J.P., Blancheton, J.P., 2002. Bacteria and nutrients nitrogen and carbon - in a recirculating system for sea bass production, Aquacult. Eng. 26, 111127.

Mata, L., Silva J., Schuenhoff A., Santos, R., 2004, The effects of light and temperature on the photosynthesis of the Asparagopsis armata tetrasporophyte (Falkenbergia rufolanosa), cultivated in tanks, Aquaculture, In press

McCarthy, J.F., Shugart, L.R., 1990. Biological markers of environmental contamination. In: McCarthy, J.F., Shugart, L.R. (Eds), Biomarkers of environmental contamination. Lewis Publishers, Boca Raton, FL, USA. pp. 3-16.

Murphy, J., Riley, J.P., 1962. A modified single solution method for the determination of phosphate in natural waters. Anal. Chim. Acta 12, 162-170.

Pagand, P., Blancheton, J.P., Casellas, C., 2000a. A model for predicting the quantities of dissolved inorganic nitrogen released in effluents from a sea bass (Dicentrarchus labrax) recirculating water system, Aquacult. Eng. 22, 137-153.

Pagand, P., Blancheton J.P., Lemoalle, J., Casellas, C., 2000b. The use of high rate algal ponds for the treatment of marine effluent from a recirculating fish rearing system, Aquac. Res. 31, 729-736.

Paoletti, F., Aldinucci, D., Molaci, A., Caparrini, A., 1986. A sensitive spectrophotometric method for the determination of superoxide dismutase activity in tissue extracts. Analytical Biochemistry 154, 536-541.

Schmitt, C.J., Dethloff, GM., 2000. Biomonitoring of Environmental Status and Trends (BEST) Program: selected methods for monitoring chemical contaminants and their effects in aquatic ecosystems U.S. Geological Survey, Biological Resources Division, Columbia, (MO): Information and Technology Report USGS/BRD-2000--0005. 81 pp.

Schuenhoff, A., Mata, L., Santos R., The tetrasporophyte of Asparagopsis armata as a novel seaweed biofilter. Aquaculture, In press.

Slooff, W., van Kreijl, C.F., Baars, A.J., 1983. Relative liver weights and xenobiotic metabolizing enzymes of fish from polluted surface waters in the Netherlands. Aquatic Toxicology 4, 1-14.

Solorzano, L., 1969. Determination of ammonia in natural waters by the phenolhypochlorite method. Limnol. Oceanogr. 14, 799-801.

Stegeman, J.J., Brouwer, M., Richard, T.D.G., Forlin, L., Fowler, B.A., Sanders, B.M., van Veld, P.A., 1992. Molecular responses to environmental contamination: enzyme and protein systems as indicatorq of chemical exposure and effect. In: Huggett R.J., Kimerly, R.A., Mehrle, P.M. Jr, Bergman, H.L. (Eds), Biomarkers: biochemical, physiological and histological markers of anthropiogenic stress. Lewis Ppublishers, Chelsea, MI, USA, pp. 235-335.

Treguer, P., Le Corre, P., 1974. Manuel d'analyse des sels nutritifs dans l'eau de mer : utilisation de l’Autoanalyzer II Technicon. Lab. Océanologie Chimique de l’UBO. Brest, France pp.

Wood, A., Scheepers, J., Hills, M., 1989. Combined artificial wetland and high rate algal pond for wastewater treatment and protein production. Wat. Sci. Tech. 21, 659-668. 
Table 1: Main operational features of the components of the system (from Deviller et al, 2004).

\begin{tabular}{llll} 
Number & Components & Functions & Characteristics \\
\hline 1 & Fish tank & Fish stocking & $2 \mathrm{~m}^{3}$ \\
\hline 2 & Particle trap & Faeces and uneaten food collection & \\
\hline 3 & Mechanical filter & Removal of small particles & $30 \mu \mathrm{m}$ mesh filter \\
\hline 4 & Pumping tank & pH regulation & $0.5 \mathrm{~m}^{3}$ \\
& & Replacement water & Soda adding, Sand filtered \\
& & Thermoregulation & Heat exchanger or rheostat \\
\hline 5 & Pump & Recirculation of water & $10 \mathrm{~m}^{3} / \mathrm{h}$ \\
\hline 6 & UV lamp & Bacteria control & $20.10^{-3} \mathrm{~J} / \mathrm{cm}^{2}$ \\
\hline 7 & Biological filter & Nitrification & $0.7 \mathrm{~m}^{3}$ Biogrog ${ }^{\circledR}$ \\
\hline 8 & Packed column & CO ${ }_{2}$ stripping & $6 \mathrm{~m}^{3}: 12 \mathrm{~m}^{2} \times 0.5$ m Paddle wheel
\end{tabular}


Table 2: Concentrations of TAN, $\mathrm{NO}_{2}-\mathrm{N}, \mathrm{NO}_{3}-\mathrm{N}$ and $\mathrm{PO}_{4}-\mathrm{P}$ in the rearing water (from Deviller et al, 2004).

\begin{tabular}{|c|c|c|c|c|c|c|c|}
\hline Season & $\begin{array}{l}\text { Rearing } \\
\text { systems }\end{array}$ & $\begin{array}{l}\mathbf{P}-\mathbf{P O}_{4}{ }^{3-} \\
\left(\mathrm{mg} . \mathrm{l}^{-1}\right)\end{array}$ & $\begin{array}{l}\text { N-NID } \\
\left(\mathrm{mg} . \mathrm{l}^{-1}\right)\end{array}$ & $\begin{array}{l}{\mathrm{N}-\mathrm{NO}_{3}}^{-} \\
\left(\mathrm{mg} . \mathrm{l}^{-1}\right)\end{array}$ & $\begin{array}{l}\mathbf{N}-\mathrm{NO}_{2}^{-} \\
\left(\mathrm{mg} \cdot \mathrm{l}^{-1}\right)\end{array}$ & $\begin{array}{l}\text { N-TAN } \\
\left(\mathrm{mg} . \mathrm{l}^{-1}\right)\end{array}$ & $\begin{array}{l}\text { N-UIA } \\
\left(\mu g . l^{-1}\right)\end{array}$ \\
\hline \multirow{4}{*}{$\begin{array}{l}\text { Winter } \\
(\mathrm{N}=26)\end{array}$} & FTS & $0.02 \pm 0.01$ & $0.2 \pm 0.1$ & $0.2 \pm 0.1$ & $0.00 \pm 0.00$ & $0.09 \pm 0.04$ & $3.0 \pm 2.0$ \\
\hline & RAS & $2.00 \pm 0.28^{*}$ & $14.9 \pm 2.7^{*}$ & $14.7 \pm 2.7^{*}$ & $0.08 \pm 0.04$ & $0.12 \pm 0.07$ & $2.0 \pm 2.0$ \\
\hline & RAS+HR & $1.57 \pm 0.41^{*}$ & $10.0 \pm 2.2^{*}$ & $9.8 \pm 2.2^{*}$ & $0.05 \pm 0.02$ & $0.14 \pm 0.08$ & $3.0 \pm 2.0$ \\
\hline & AP & & & & & & \\
\hline \multirow{4}{*}{$\begin{array}{l}\text { Spring } \\
(\mathrm{N}=26)\end{array}$} & FTS & $0.02 \pm 0.01$ & $0.3 \pm 0.2$ & $0.1 \pm 0.2$ & $0.02 \pm 0.01$ & $0.12 \pm 0.09$ & $4.0 \pm 4.0$ \\
\hline & RAS & $1.67 \pm 0.37$ & $17.3 \pm 4.0 *$ & $16.9 \pm 4.0^{*}$ & $0.13 \pm 0.06$ & $0.22 \pm 0.14$ & $1.0 \pm 1.0$ \\
\hline & RAS+HR & $1.52 \pm 0.28$ & $11.3 \pm 2.5^{*}$ & $10.8 \pm 2.4^{*}$ & $0.15 \pm 0.07$ & $0.29 \pm 0.15$ & $5.0 \pm 2.0$ \\
\hline & $\mathrm{AP}$ & & & & & & \\
\hline \multirow{4}{*}{$\begin{array}{l}\text { Summer } \\
(\mathrm{N}=24)\end{array}$} & FTS & $0.02 \pm 0.01$ & $0.2 \pm 0.1$ & $0.2 \pm 0.1$ & $0.00 \pm 0.00$ & $0.16 \pm 0.04$ & $6.0 \pm 2.0$ \\
\hline & RAS & $1.44 \pm 0.31^{*}$ & $16.3 \pm 5.0 *$ & $15.9 \pm 4.9 *$ & $0.11 \pm 0.04$ & $0.32 \pm 0.07$ & $2.0 \pm 1.0$ \\
\hline & RAS+HR & $1.19 \pm 0.29 *$ & $12.3 \pm 2.1^{*}$ & $11.9 \pm 2.0^{*}$ & $0.10 \pm 0.02$ & $0.35 \pm 0.13$ & $5.0 \pm 4.0$ \\
\hline & AP & & & & & & \\
\hline \multirow{4}{*}{$\begin{array}{l}\text { Autumn } \\
(\mathrm{N}=19)\end{array}$} & FTS & $0.05 \pm 0.02$ & $0.4 \pm 0.1$ & $0.1 \pm 0.1$ & $0.00 \pm 0.00$ & $0.33 \pm 0.06$ & $8.0 \pm 1.0$ \\
\hline & RAS & $1.52 \pm 0.25$ & $15.4 \pm 4.4$ & $14.9 \pm 4.4$ & $0.14 \pm 0.08$ & $0.40 \pm 0.08$ & $1.0 \pm 0.1$ \\
\hline & RAS+HR & $1.82 \pm 0.18$ & $16.0 \pm 3.2$ & $15.5 \pm 3.2$ & $0.13 \pm 0.03$ & $0.40 \pm 0.10$ & $2.0 \pm 1.0$ \\
\hline & $\mathrm{AP}$ & & & & & & \\
\hline \multirow{4}{*}{$\begin{array}{l}\text { Annual } \\
(\mathrm{N}=95)\end{array}$} & FTS & $0.03 \pm 0.02$ & $0.4 \pm 0.2$ & $0.1 \pm 0.1$ & $0.01 \pm 0.01$ & $0.24 \pm 0.16$ & $5.0 \pm 3.0$ \\
\hline & RAS & $1.56 \pm 0.33^{*}$ & $17.3 \pm 5.2^{*}$ & $16.9 \pm 5.2^{*}$ & $0.12 \pm 0.06$ & $0.30 \pm 0.12$ & $2.0 \pm 1.0$ \\
\hline & RAS+HR & $1.70 \pm 0.52 *$ & $14.8 \pm 5.3^{*}$ & $14.5 \pm 5.1 *$ & $0.13 \pm 0.05$ & $0.34 \pm 0.12$ & $4.0 \pm 3.0$ \\
\hline & AP & & & & & & \\
\hline
\end{tabular}

Values are means \pm standard deviation. $*$ Statistically significant difference $(\mathrm{p}<0.05)$ between RAS and RAS+HRAP. 
Table 3: Seasonal and annual removal rates of dissolved nutrients by the two HRAP comparing nutrients concentrations in the RAS and the RAS+HRAP

$$
\text { TAN } \quad \mathrm{NO}_{3}{ }^{-} \text {removal } \mathrm{NO}_{2}{ }^{-} \text {removal DIN removal } \mathrm{PO} 4 \text { removal Daily Daily light }
$$

removal

$\left(\mathrm{gN} \cdot \mathrm{m}^{-2} \cdot \mathrm{d}^{-1}\right) \quad\left(\mathrm{gN} \cdot \mathrm{m}^{-2} \cdot \mathrm{d}^{-1}\right) \quad\left(\mathrm{gN} \cdot \mathrm{m}^{-2} \cdot \mathrm{d}^{-1}\right) \quad\left(\mathrm{gN} \cdot \mathrm{m}^{-2} \cdot \mathrm{d}^{-1}\right) \quad\left(\mathrm{gP} \cdot \mathrm{m}^{-2} \cdot \mathrm{d}^{-1}\right)$
Temper.

$\left({ }^{\circ} \mathrm{C}\right) \quad\left(\mu \mathrm{E} \cdot \mathrm{m}^{-2} \cdot \mathrm{s}^{-1}\right)$

\begin{tabular}{|c|c|c|c|c|c|c|c|}
\hline Spring & & & & & & & \\
\hline$\mu$ & -0.013 & 0.27 & -0.006 & 0.25 & -0.024 & 19 & 85 \\
\hline Summe & & & & & & & \\
\hline$\mu$ & -0.005 & 0.49 & 0.001 & 0.49 & 0.027 & 25 & 89 \\
\hline Autum & & & & & & & \\
\hline$\mu$ & 0.009 & 0.27 & 0.005 & 0.28 & -0.009 & 10 & 50 \\
\hline Wint & & & & & & & \\
\hline$\mu$ & -0.002 & 0.09 & 0.001 & 0.09 & 0.002 & 12 & 46 \\
\hline$\overline{\text { Апnиа }}$ & & & & & & & \\
\hline$\mu$ & -0.005 & 0.37 & -0.0001 & 0.36 & 0.008 & 17 & 70 \\
\hline
\end{tabular}


Table 4: Biochemical biomarkers in livers of sea bass after one year of rearing in three different systems (means $\pm \mathrm{SD}$ ).

\begin{tabular}{|c|c|c|c|}
\hline & FTS & RAS & RAS+HRAP \\
\hline $\mathrm{LP}^{a}$ & $34.4 \pm 8.8$ & $37.5 \pm 10.6$ & $38.7 \pm 9.0$ \\
\hline $\mathrm{SOD}^{b}$ & $15724 \pm 9576$ & $19424 \pm 7402^{*}$ & $15096 \pm 4933$ \\
\hline EROD $^{c}$ & $8.1 \pm 5.7$ & $12.2 \pm 6.7^{*}$ & $13.1 \pm 6.6^{*}$ \\
\hline
\end{tabular}


Table 5: The mean metal concentrations in the muscle and liver of fish in each rearing system

\begin{tabular}{|c|c|c|c|c|c|c|}
\hline Rearing system & \multicolumn{2}{|c|}{ FTS } & \multicolumn{2}{|r|}{ RAS } & \multicolumn{2}{|c|}{ RAS+HRAP } \\
\hline $\begin{array}{l}\text { Number of fish } \\
\text { analysed }\end{array}$ & \multicolumn{2}{|c|}{10} & \multicolumn{2}{|r|}{11} & \multicolumn{2}{|r|}{6} \\
\hline Fish length (mm) & \multicolumn{2}{|c|}{$325 \pm 27^{a}$} & \multicolumn{2}{|c|}{$303 \pm 25^{a}$} & \multicolumn{2}{|c|}{$298 \pm 40^{a}$} \\
\hline $\begin{array}{c}\text { Fish weight } \\
\text { (g) }\end{array}$ & \multicolumn{2}{|c|}{$452 \pm 113^{a}$} & \multicolumn{2}{|c|}{$393 \pm 94^{a}$} & \multicolumn{2}{|c|}{$362 \pm 181^{a}$} \\
\hline Tissue & Muscle & Liver & Muscle & Liver & Muscle & Liver \\
\hline Chromium & $\begin{array}{l}0.05 \pm 0.09 \\
(0.00-0.32)^{a}\end{array}$ & $\begin{array}{l}0.04 \pm 0.09 \\
(0.00-0.27)^{a} \\
\end{array}$ & $\begin{array}{l}0.25 \pm 0.14 \\
(0.00-0.38)^{b}\end{array}$ & $\begin{array}{l}0.12 \pm 0.08(0.00- \\
0.23)^{b}\end{array}$ & $\begin{array}{l}0.24 \pm 0.13 \\
(0.00-0.09)^{b}\end{array}$ & $\begin{array}{l}0.13 \pm 0.08 \\
(0.01-0.26)^{b}\end{array}$ \\
\hline Manganese & $\begin{array}{l}0.50 \pm 0.46 \\
(0.00-1.21)^{a}\end{array}$ & $\begin{array}{l}1.88 \pm 0.52 \\
(1.11-2.59)^{a}\end{array}$ & $\begin{array}{l}2.59 \pm 2.56 \\
(0.80-8.69)^{b}\end{array}$ & $\begin{array}{l}2.44 \pm 0.78 \text { (1.47- } \\
3.97)^{a}\end{array}$ & $\begin{array}{l}1.32 \pm 0.66 \\
(0.74-2.59)^{a, b}\end{array}$ & $\begin{array}{l}2.15 \pm 0.53 \\
(1.58-2.93)^{a}\end{array}$ \\
\hline Cobalt & $\begin{array}{l}0.004 \pm 0.007 \\
(0.000-0.024)^{a}\end{array}$ & $\begin{array}{l}0.029 \pm 0.013 \\
(0.000-0.048)^{a}\end{array}$ & $\begin{array}{l}0.032 \pm 0.038 \\
(0.000-0.097)^{b}\end{array}$ & $\begin{array}{l}0.045 \pm 0.015(0.028- \\
0.071)^{b}\end{array}$ & $\begin{array}{l}0.012 \pm 0.012 \\
(0.002-\end{array}$ & $\begin{array}{l}0.048 \pm 0.019 \\
(0.024-0.070)^{a, b}\end{array}$ \\
\hline Nickel & $\begin{array}{l}0.16 \pm 0.43 \\
(0.00-1.35)^{a}\end{array}$ & $\begin{array}{l}0.08 \pm 0.21 \\
(0.00-0.65)^{a}\end{array}$ & $\begin{array}{l}0.59 \pm 1.06 \\
(0.00-0.61)^{b}\end{array}$ & $\begin{array}{l}0.03 \pm 0.05(0.00- \\
0.12)^{a}\end{array}$ & $\begin{array}{l}2.74 \pm 5.73 \\
(0.00-14.39)^{a, b}\end{array}$ & $\begin{array}{l}0.13 \pm 0.15 \\
(0.00-0.40)^{a}\end{array}$ \\
\hline Copper & $\begin{array}{l}0.75 \pm 2.08 \\
(0.00-6.60)^{a}\end{array}$ & $\begin{array}{l}\text { 233+57 (137- } \\
313)^{a}\end{array}$ & $\begin{array}{l}0.98 \pm 0.95 \\
(0.00-3.48)^{b}\end{array}$ & $237 \pm 82(87-352)^{a}$ & $\begin{array}{l}0.40 \pm 0.30 \\
(0.19-0.96)^{a, b}\end{array}$ & $\begin{array}{l}232 \pm 77(155- \\
327)^{a}\end{array}$ \\
\hline Zinc & $\begin{array}{l}13.5 \pm 9.9(1.0- \\
32.8)^{a}\end{array}$ & $\begin{array}{l}84.3 \pm 9.6(68.8- \\
103.5)^{a}\end{array}$ & $\begin{array}{l}19.9 \pm 12.7 \\
(1.09-37.9)^{a}\end{array}$ & $\begin{array}{l}\text { 83.1 } 25.6 \text { (41.9- } \\
133.3)^{a}\end{array}$ & $\begin{array}{l}20.0 \pm 9.7 \\
(11.52-38.39)^{a}\end{array}$ & $\begin{array}{l}85.0 \pm 16.2 \\
(67.9-112.6)^{a}\end{array}$ \\
\hline Arsenic & $\begin{array}{l}6.85 \pm 1.38 \\
(4.99-9.22)^{a}\end{array}$ & $\begin{array}{l}2.39 \pm 0.34 \\
(1.98-2.98)^{a}\end{array}$ & $\begin{array}{l}9.80 \pm 1.18 \\
(7.87-11.38)^{b}\end{array}$ & $\begin{array}{l}2.55 \pm 0.54 \text { (1.29- } \\
3.26)^{a}\end{array}$ & $\begin{array}{l}8.59 \pm 1.33 \\
(6.38-10.06)^{b}\end{array}$ & $\begin{array}{l}2.85 \pm 0.56 \\
(2.42-3.96)^{a}\end{array}$ \\
\hline Silver & $\begin{array}{l}0.17 \pm 0.38 \\
(0.00-1.11)^{a}\end{array}$ & $\begin{array}{l}0.44 \pm 0.15 \\
(0.24-0.63)^{a}\end{array}$ & $\begin{array}{l}0.44 \pm 1.24 \\
(0.00-4.18)^{a}\end{array}$ & $\begin{array}{l}0.48 \pm 0.30 \text { (0.13- } \\
1.05)^{a}\end{array}$ & ND & $\begin{array}{l}0.35 \pm 0.19 \\
(0.14-0.63)^{a}\end{array}$ \\
\hline Cadmium & $\begin{array}{l}0.003 \pm 0.006 \\
(0.000-0.020)^{a}\end{array}$ & $\begin{array}{l}0.25 \pm 0.13 \\
(0.00-0.46)^{a}\end{array}$ & $\begin{array}{l}0.014 \pm 0.022 \\
(0.000-0.073)^{a}\end{array}$ & $\begin{array}{l}0.94 \pm 1.67(0.27- \\
5.94)^{b}\end{array}$ & $\begin{array}{l}0.005 \pm 0.006 \\
(0.000-0.017)^{a}\end{array}$ & $\begin{array}{l}0.32 \pm 0.05 \\
(0.28-0.40)^{a, b}\end{array}$ \\
\hline Tin & $\begin{array}{l}0.019 \pm 0.052 \\
(0.000-0.167)^{a}\end{array}$ & $\begin{array}{l}0.043 \pm 0.078 \\
(0.000-0.249)^{a}\end{array}$ & $\begin{array}{l}0.001 \pm 0.003 \\
(0.000-0.007)^{a}\end{array}$ & $\begin{array}{l}0.009 \pm 0.009(0.000- \\
0.025)^{a}\end{array}$ & $\begin{array}{l}0.002 \pm 0.004 \\
(0.000-0.008)^{a}\end{array}$ & $\begin{array}{l}0.001 \pm 0.002 \\
(0.000-0.005)^{b}\end{array}$ \\
\hline Thallium & $\begin{array}{l}0.001 \pm 0.001 \\
(0.000-0.003)^{a}\end{array}$ & $\begin{array}{l}0.003 \pm 0.002 \\
(0.000-0.005)^{a}\end{array}$ & $\begin{array}{l}0.005 \pm 0.008 \\
(0.000-0.028)^{b}\end{array}$ & $\begin{array}{l}0.004 \pm 0.002(0.001- \\
0.010)^{a}\end{array}$ & $\begin{array}{l}0.002 \pm 0.001 \\
(0.001-\end{array}$ & $\begin{array}{l}0.004 \pm 0.001 \\
(0.003-0.006)^{a}\end{array}$ \\
\hline Lead & $\begin{array}{l}0.049 \pm 0.106 \\
(0.000-0.335)^{a}\end{array}$ & $\begin{array}{l}0.006 \pm 0.012 \\
(0.000-0.036)^{a}\end{array}$ & $\begin{array}{l}0.120 \pm 0.128 \\
(0.000-0.379)^{a}\end{array}$ & $\begin{array}{l}0.070 \pm 0.078(0.000- \\
0.214)^{b}\end{array}$ & $\begin{array}{l}0.044 \pm 0.086 \\
(0.000-0.218)^{a}\end{array}$ & $\begin{array}{l}0.049 \pm 0.092 \\
(0.000-0.237)^{a, b}\end{array}$ \\
\hline
\end{tabular}

Values with no common letter superscript are significantly different $(\mathrm{p}<0.05)$. ND: non determined 


\section{Caption of figures}

Fig.1 Schematic diagram (not to scale) of the rearing systems: FTS (1,6,8\&9); RAS (1 - 9); RAS+HRAP (1 - 10); numbers are explained in Table 1

Fig.2 Water quality parameters (temperature, oxygen concentration, salinity and $\mathrm{pH}$ ) recorded within the rearing systems (from Deviller et al, 2004).

Fig.3 Averages weight and density of fish in the three recirculating systems over one year (Errors bars: \pm SD) (from Deviller et al, 2004).

Fig.4 Cumulative mortality rate of fish in the three rearing systems over one year (from Deviller et al, 2004). 


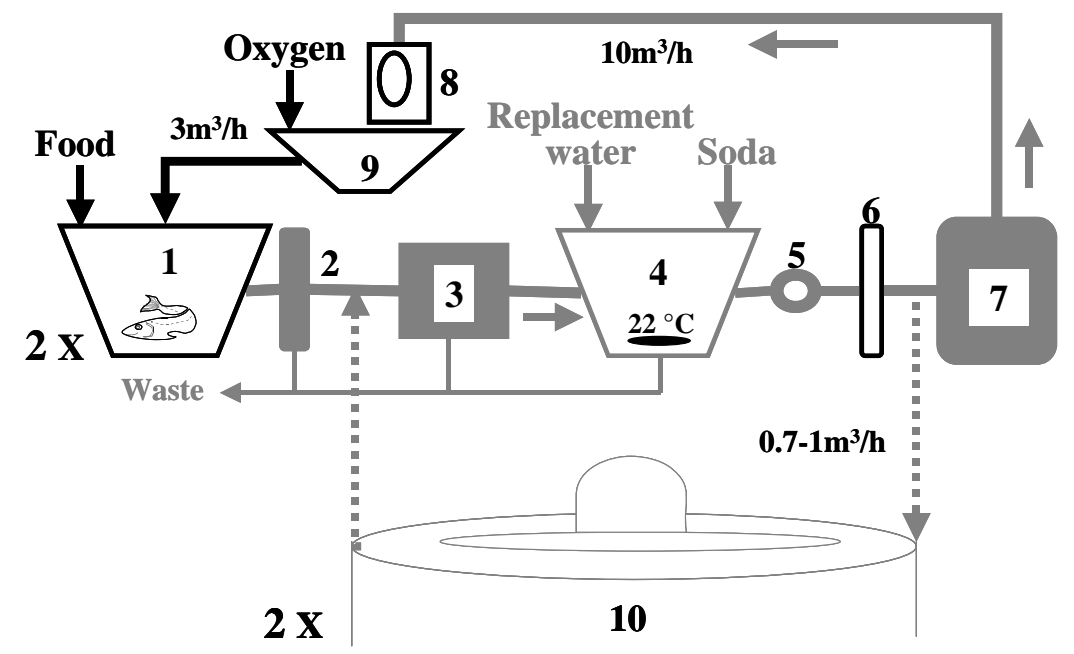

Fig. 1

All systems Recirculating systems - " - " High Rate Algae Pond 

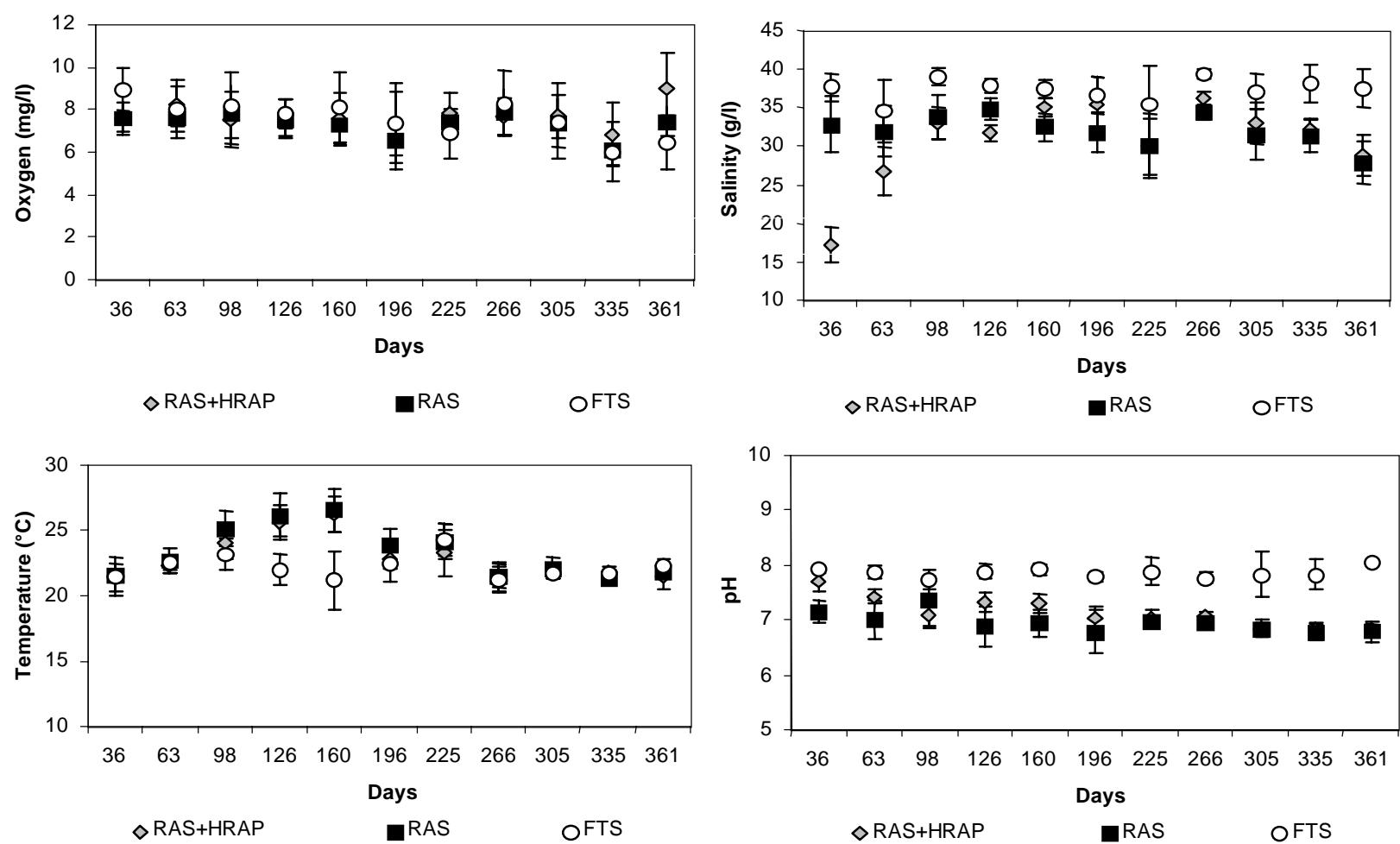

Fig. 2 


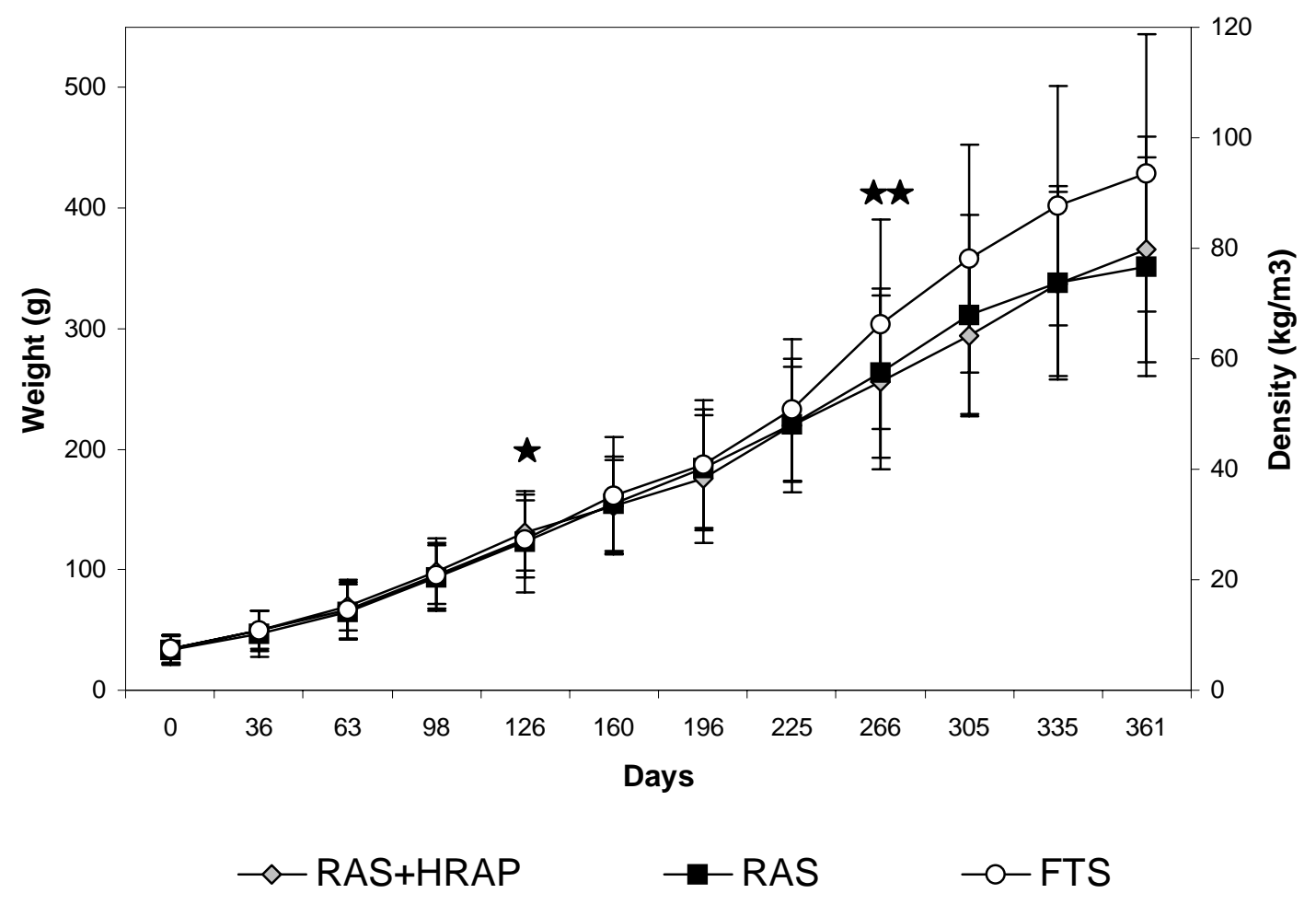

Fig. 3 


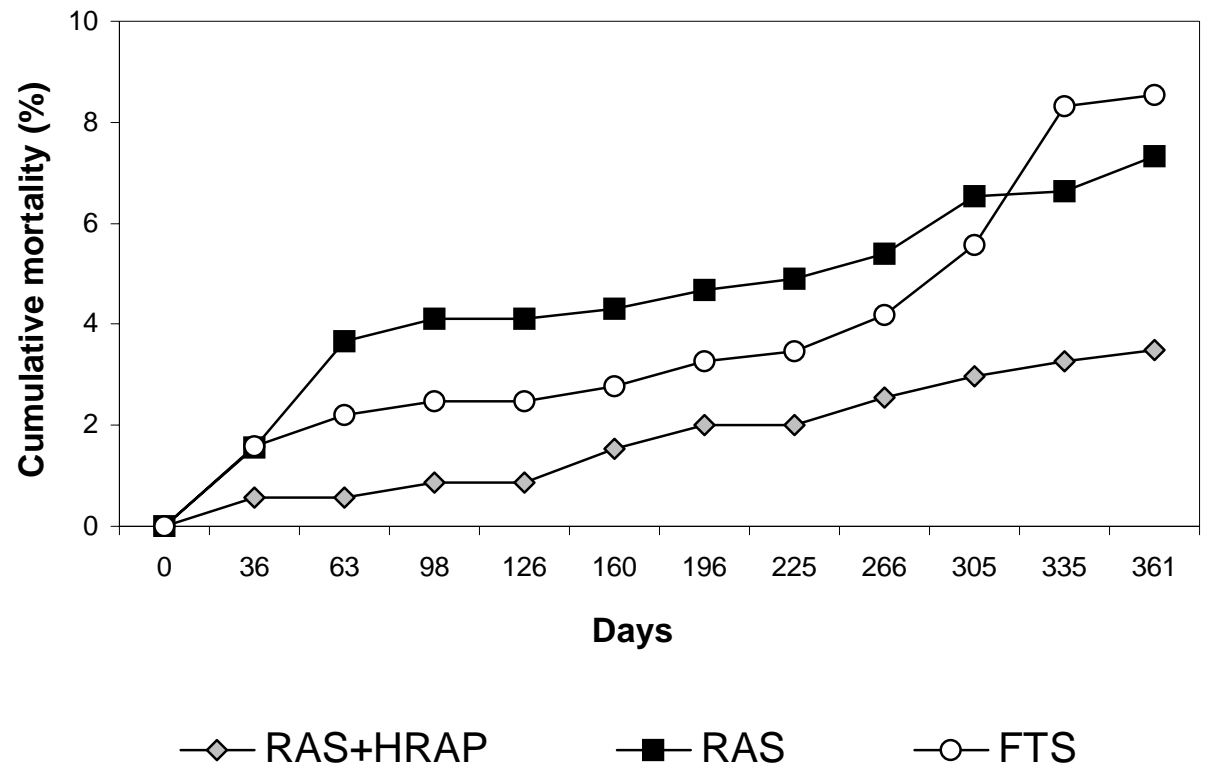

Fig. 4 